\title{
Farmers' willingness to take part in Sorghum-based Innovation Platform in Niger State, Nigeria
}

\author{
Ibrahim Mohammed ${ }^{1}$ and Nnanna Ugochukwu Adonikam ${ }^{2}$
}

\begin{abstract}
The research examined the determinants of farmers' willingness to partake in sorghumbased innovation platforms, ascertained the factors influencing their willingness and constraints to their participation. Structured questionnaire was used to elicit data from 350 registered respondents drawn from Niger State, Nigeria. Data were analysed using descriptive statistics, Probit and multiple regression. The result reveals that the farmers' mean age was 40 . About $85 \%$ of them were married with a household size of 1-5 persons. The result of probit showed that availability of active labour force, income from the sorghum, number of trainings, access to extension service and market access were the major determinants to farmers' participation in sorghum innovation platform. Major constraints were, untimely meetings, poor means of transportation, information gap and complexity of innovation. The study concludes that farmers were willing to participate in sorghum-based innovation platform but do not have enough capital base. The study recommends that farmers should be linked up with credit institutions and timely meetings should be conducted.
\end{abstract}

Keywords: Innovation; Sorghum; Perception; Nigeria

\section{INTRODUCTION}

Governments in various developing countries are seeking effective ways of mainstreaming agricultural research in the economic arena (DRTD, 2008). In Nigeria, just like in every other African country, there has been policy shift, over the decades, from investing in the establishment of National Agricultural Research Systems (NARS), to a two-step system of a

NARS complemented by a state run agricultural extension delivery system, to current thinking that a pluralistic, private sector driven space could provide the most effective and sustainable way for mainstreaming science and technology in agriculture.Various agricultural research institutions have generated technologies and other outputs that are either not adopted if adoptable or not transferred appropriately to the end users. The resultant effect of this scenario is stagnation in the state of rural poverty despite series of investment by the development partners and government of different countries. The

\footnotetext{
${ }^{1}$ Department of Agricultural Extension and Rural Development, Federal University of Technology, Minna, Niger State, Nigeria ${ }^{2}$ ATASP-1 Outreach Component, ATASP-1 National Office, Abuja. Nigeria.
} 
Farmers willingness to take part in Sorghum-based Innovation Platform in Niger State, Nigeria

poor performance of the agricultural sector has been viewed by Agricultural Research Development (ARD) actors as a problem of the process rather than that of availability of technologies (Ugbe, 2010). Under this arrangement, each stakeholder group carries out the task they handle best, based on their competencies, resource domain and mode of operation.

Based on the above, the Agricultural Transformation Agenda Support Programme Phase-1 (ATASP-1) a Federal Government programme assisted by the African Development Bank (AfDB) utilizes the Value Chain Innovation Platform (VCIP) approach to bring different value chain players together, to be able to solve their problems within their capacity. ATASP-1 which was constituted based on Staple Crop Processing Zones (SCPZs) as a pilot project that focuses on three commodities (such as Rice, Cassava and Sorghum) has four SCPZs Bida-Badeggi SCPZ in Niger State.

The Agricultural Transformation Agenda Support Programme Phase-1 has been operating in Nigeria creating awareness on the need and benefits of farmers participation in VCIPs, just like other programmes in the past that have sought to increase the level of participation of farmers and other stakeholders but the level of participation by the farmers and other stakeholders have not been encouraging. And despite the overwhelming benefits of Value Chain Innovation Platforms especially in transforming different agricultural value chains and ensuring sustainability in agriculture, farmers have not fully understood the benefits and have not really adopted the approach of the platforms and are less willing to participate fully and be able to solve their problems within the platform. In addition, not much is done to establish the factors that influence farmers' willingness to participate in this regard in Nigeria especially in the study area. Based on these facts, this study seeks to examine the determinants of the farmers' willingness to participate and factors that influence the farmers' willingness decision in this regard so that the future programmes can be well designed to ensure farmers participation in the innovation platform and reap the potential benefits.The aim of the study is to assess farmers' willingness decision to participate in ATASP-1 sorghum value chain innovation platform in Niger State, Nigeria.

The specific objectives of the study were to :

- describe the socio-economic characteristics of ATASP-1 sorghum farmers;

- examine the determinants of farmers' willingness to participate in the innovation platform;

- ascertain the socio-economics factors influencing their willingness;

- examine farmers' perceived constraints to participation in sorghum Value Chain.

\section{METHODOLOGY}

This study was conducted in Niger State of Nigeria. Niger State is located in the North Central zone of Nigeria and classified as one of the largest states in the country in terms of land mass spanning over 86,000 
$\mathrm{km} 2$ in land area with $80 \%$ of the land mass conducive for agriculture (Tologbonse, 2008). ATASP-1 is operating in Bida-Badeggi SCPZ comprising of only Niger State; The Programme is been implemented in seven selected Local Government Areas (LGAs) of Niger State namely: Lapai, Gbako, Lavun, Wushishi, Mokwa, Agaie and Katcha LGAs and The ATASP-1 registered sorghum value chain farmers in both states formed the basis of this study.

A multistage sampling technique was adopted for the study. The first step involved the random selection of two (Gbako and Wushishi) LGAs each from the LGAs benefiting in each State and participating in the sorghum production under the programme. The second stage involved the random selection of three communities each from the LGAs. The third stage involved a random selection of 350 farmers from the communities based on proportion of the total sample of registered farmers derived with the Taro Yamane's method from the total population of registered farmers in the areas. Primary data were collected and analysed using both descriptive and inferential statistics such as Probit regression model, multiple regression model and t test statistics.

\section{FINDINGS AND DISCUSSION}

\section{Socio-economic Characteristics of Farmers}

Socio economic characteristics considered in this study were age, education, gender, marital status, active household size, number of training received, market access per week, income from sorghum and amount willing to invest. The result in Table 1 reveals that $77 \%$ of the respondents were under 39 years. This implies that the younger ones have started realising the potential of taking up agriculture. Majority had formal education. This may account for the high level adoption of some of technologies disseminated by the programme. Since a greater percentage have high level of formal education, their ability to make independent and informed decisions might have been high. Majority (86\%) were male and married, Majority (71\%) had a house hold size of 1-5 persons. The implication is that the families with higher number of family members contributing to family labour tend to invest more labour. Majority (86\%) received 1-3 extension trainings per week. This implies that since the farmers already have cordial relationship with the other value chain actors, they will be able to function effectively in the innovation platform. Majority (67\%) had access to market twice a week. Majority (77\%) had income ranging from 51,000 to 100,000 . This accounts for the low adoption in the mechanization technologies and implies that with the low income from sorghum value chain source, the farmers only adopt cheaper technologies. This means that farmers in the study area are willing to invest on the programme but their capital base was low.

\section{Determinants of Farmers' willingness to participate in sorghum value chain}

The result in Table 3 show that availability of active labour force, income from the sorghum, number of training, access to extension service and market access were the major determinant to farmers participation in sorghum innovation platform. This is consistent with the study 
Farmers willingness to take part in Sorghum-based Innovation Platform in Niger State, Nigeria

Table 1.

Socio-economic Characteristics of the respondents

\begin{tabular}{|c|c|c|c|}
\hline SI. No. & Variables & Frequency & Percentage \\
\hline I & Age (in years) & & \\
\hline 1 & $1-39$ & 270 & 77.1 \\
\hline 2 & $40-80$ & 80 & 22.9 \\
\hline \multirow[t]{2}{*}{3} & $>80$ & 0 & 0 \\
\hline & Mean $=40$ & & \\
\hline II & Education & & \\
\hline 1 & Non-Formal & 5 & 1.4 \\
\hline 2 & Formal & 345 & 98.6 \\
\hline III & Gender & & \\
\hline 1 & Male & 300 & 85.7 \\
\hline 2 & Female & 50 & 14.3 \\
\hline IV & Marital Status & & \\
\hline 1 & Single & 20 & 5.7 \\
\hline 2 & Married & 300 & 85.7 \\
\hline 3 & Separated & 10 & 2.86 \\
\hline 4 & Divorce & 21 & 6.0 \\
\hline V & Active Household size & & \\
\hline 1 & $1-5$ & 250 & 71.4 \\
\hline 2 & $6-10$ & 60 & 17.1 \\
\hline 3 & $>10$ & 40 & 11.4 \\
\hline VI & Number of trainings per month & & \\
\hline 1 & $1-3$ & 300 & 85.7 \\
\hline 2 & $4-6$ & 45 & 12.9 \\
\hline 3 & $>6$ & 5 & 1.4 \\
\hline VII & Market access per week & & \\
\hline 1 & Once & 100 & 28.6 \\
\hline 2 & Twice & 240 & 68.6 \\
\hline 3 & Thrice & 10 & 2.9 \\
\hline
\end{tabular}




\begin{tabular}{|c|l|c|c|}
\hline SI. No. & \multicolumn{1}{|c|}{ Variables } & Frequency & Percentage \\
\hline VIII & Income from sorghum & & \\
\hline 1 & $1,000-50,000$ & 70 & 20 \\
\hline 2 & $51,000-100,000$ & 270 & 77.1 \\
\hline 3 & $>100,000$ & 10 & 2.9 \\
\hline IX & Amount willing to invest & & 1.4 \\
\hline 1 & $1,000-5,000$ & 5 & 5.7 \\
\hline 2 & $6,000-10,000$ & 20 & 92.6 \\
\hline 3 & $>10,000$ & 325 & \\
\hline
\end{tabular}

of Martey et al. (2013) which revealed that increase in family size increases the land for agricultural production. Market access was also significant with willingness to participate. This means that as the farmers' access to market increased, they were more likely to be willing to participate. Socio-Economic Factors Influencing Farmers'
Willingness Decision

The multiple linear regression model results shown in Table 3 indicate that age, educational

Table 2.

Determinants of Farmers' Willingness to Participate in Sorghum VCIPs

\begin{tabular}{|c|c|c|c|c|c|}
\hline \multirow[t]{2}{*}{ SI. No. } & Determinants & \multicolumn{3}{|c|}{ Values } & \multirow[t]{2}{*}{$\begin{array}{c}\text { Marginal } \\
\text { Effect }\end{array}$} \\
\hline & Willingness to Participate & Coef. & t-value & P-value & \\
\hline 1 & $\begin{array}{l}\text { Active labour contributing to } \\
\text { the programme }\end{array}$ & .34029 & 2.000 & $0.046^{* *}$ & 0.0013 \\
\hline 2 & Income from Sorghum sources & $7.35 \mathrm{e}-06$ & 1.930 & $0.004^{* * *}$ & 0.0024 \\
\hline 3 & Number of training & .634234 & 3.280 & $0.001^{* * *}$ & 0.0029 \\
\hline 4 & Access to Extension Services & 6.87650 & 2.675 & $0.003^{* * *}$ & 0.0144 \\
\hline 5 & Market Access & 0.00013 & 1.740 & $0.082^{*}$ & $1.51 \mathrm{E}-07$ \\
\hline & _Cons & -1.0523 & -0.500 & 0.616 & \\
\hline & Number of obs & & 350 & & \\
\hline & Log likelihood & & -18.31 & & \\
\hline & Prob> chi2 & & 0.000 & & \\
\hline & Pseudo R2 & & 0.795 & & \\
\hline & LR chi2(22) & & 67.77 & & \\
\hline
\end{tabular}

Note: ${ }^{*}$ implies significant at $10 \%,{ }^{* *}$ implies significant at $5 \%$ and ${ }^{* * *}$ implies significant at $1 \%$ 
Farmers willingness to take part in Sorghum-based Innovation Platform in Niger State, Nigeria

Table 3.

Socio-economic Factors Influencing Willingness to Participate in Sorghum VCIP

\begin{tabular}{|l|l|c|c|l|}
\hline \multicolumn{1}{|c|}{ Sl. No. } & \multicolumn{1}{|c|}{ Willing to invest to adopt } & Coef & t-value & \multicolumn{1}{c|}{ P-value } \\
\hline 1. & Age & 2214.02 & 2.38 & $0.019^{* *}$ \\
\hline 2. & Level of Education & 4940.18 & 2.47 & $0.023^{* *}$ \\
\hline 3. & Number of members in family Labour & -4469.88 & 2.85 & $-0.067^{*}$ \\
\hline 4. & Number of training & 8494.391 & 3.59 & $0.001^{* * *}$ \\
\cline { 2 - 5 } & Cons & - & -0.48 & 0.632 \\
\cline { 2 - 5 } & Number of obs & & \multicolumn{2}{|c|}{350} \\
\cline { 2 - 5 } & Prob> F & & \multicolumn{2}{|c|}{0.000} \\
\cline { 2 - 5 } & R Squared & & \multicolumn{2}{|c|}{0.7939} \\
\hline
\end{tabular}

Note: ${ }^{*}$ implies significant at $10 \%,{ }^{* *}$ implies significant at $5 \%$ and ${ }^{* * *}$ implies significant at $1 \%$

level, number of members in the family and number of trainings received were major socio-economic factors considered in this research work. Age was statistically significant; this means that the younger sorghum farmers were more willing to participate in sorghum VCIPs. Level of education \& house hold size was significant but negative.

Table 4.

Perceived Constraints to Sorghum Innovation Platform

\begin{tabular}{|l|l|l|l|l|l|}
\hline $\begin{array}{c}\text { Sl. } \\
\text { No. }\end{array}$ & \multicolumn{1}{|c|}{ Constraints } & $\begin{array}{c}\text { Weighted } \\
\text { Sum }\end{array}$ & $\begin{array}{c}\text { Weighted } \\
\text { mean }\end{array}$ & Ranks & \multicolumn{1}{|c|}{ Remarks } \\
\hline 1. & Untimely conduct of meeting & 950 & 2.71 & $1^{\text {st }}$ & Serious Constraint \\
\hline 2. & Poor means of transportation & 930 & 2.66 & $2^{\text {nd }}$ & Serious Constraint \\
\hline 3. & Information gap & 900 & 2.57 & $3^{\text {rd }}$ & Serious Constraint \\
\hline 4. & Complexity of innovation & 890 & 2.50 & $4^{\text {th }}$ & Serious Constraint \\
\hline 5. & Contribution not forthcoming & 850 & 2.42 & $5^{\text {th }}$ & Serious Constraint \\
\hline 6. & Distance to meeting place & 620 & 1.77 & $6^{\text {th }}$ & Not Serious Constraint \\
\hline 7. & $\begin{array}{l}\text { Weather not favourable for the } \\
\text { meeting }\end{array}$ & 580 & 1.66 & $7^{\text {th }}$ & Not Serious Constraint \\
\hline 8. & Tight schedules & 500 & 1.43 & $8^{\text {th }}$ & Not Serious Constraint \\
\hline 9. & $\begin{array}{l}\text { Conflict of interest among stake } \\
\text { holders }\end{array}$ & 450 & 1.28 & $9^{\text {th }}$ & Not Serious Constraint \\
\hline 10. & Uncertainties & 350 & 1.00 & $10^{\text {th }}$ & Not Serious Constraint \\
\hline
\end{tabular}




\section{Perceived Constraints to Participation in Sorghum Innovation Platforms}

The results in Table 4 reveal that untimely meeting, poor means of transportation, information gap and complexity of innovation were the serious constraints faced by the respondents. Conflict of meeting days with market days was found to be the most constraining factor of farmers' willingness to participate in Sorghum VCIP. The success of the Sorghum VCIP is highly dependent on the attendance of meetings by stakeholders which includes farmers. The situation becomes aggravated where there were poor means of transportation and information gap.

\section{CONCLUSION}

It is concluded that farmers are willing to participate and invest in the innovation platform but their financial base was found to be low. The study recommends that farmers should be linked up with credits institutions and meetings should be timely.

\section{REFERENCES}

DRTD (Directorate Research \& Technology Development) (2008). National Research and Development Strategy.Department of Agriculture, Pretoria 3-6.

Martey, E., Wiredu, A.N Asante, B.O., Annin, K., Dogbe, W., Attoh, C. \& Al-Hassan, R.M. (2013). Factors influencing participation in rice development projects: the case of smallholders rice farmers in Northern Ghana. International Journal of Development and Economic Sustainability, 1(2), 13-27.

Tologbonse, D. (2008). Policy Issues in Meeting Rice Farmers Agricultural Information Needs in Niger State. Journal of Agricultural Extension 12 (2): 84-94.

Ugbe, U, P. (2010). What Does Innovation Smell Like? A Conceptual Framework for Analysis and Evaluation DFID-RIU Experiments in Brokering Agricultural Innovation and Development Research into Use. Discussion paper 10. London: Department for International Development 